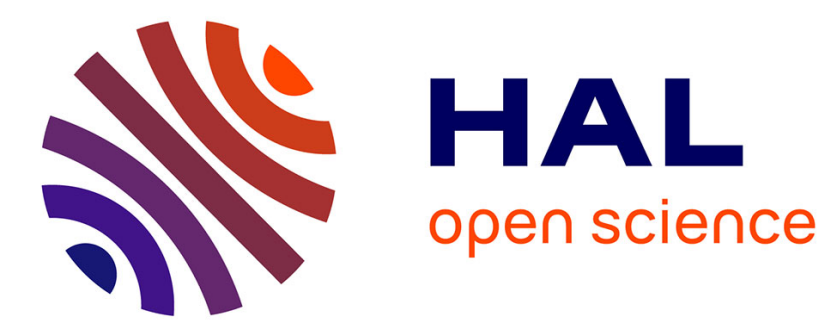

\title{
Time-Temperature-Water Content equivalence on dynamic mechanical response of Polyamide 6,6
}

Victor Fabre, Grégoire Quandalle, Sabine Cantournet, Noëlle Billon

\section{To cite this version:}

Victor Fabre, Grégoire Quandalle, Sabine Cantournet, Noëlle Billon. Time-Temperature-Water Content equivalence on dynamic mechanical response of Polyamide 6,6. The 9th International Conference on the Mechanics of Time Dependent Materials, May 2014, Montreal, Canada. hal-01112802

HAL Id: hal-01112802

https://hal-mines-paristech.archives-ouvertes.fr/hal-01112802

Submitted on 3 Feb 2015

HAL is a multi-disciplinary open access archive for the deposit and dissemination of scientific research documents, whether they are published or not. The documents may come from teaching and research institutions in France or abroad, or from public or private research centers.
L'archive ouverte pluridisciplinaire HAL, est destinée au dépôt et à la diffusion de documents scientifiques de niveau recherche, publiés ou non, émanant des établissements d'enseignement et de recherche français ou étrangers, des laboratoires publics ou privés. 


\title{
Time-Temperature-Water Content equivalence on dynamic mechanical response of Polyamide 6,6
}

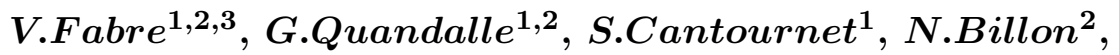 \\ 1: Centre des Matériaux, Mines Paristech, CNRS UMR 7633, BP 87, 91003 Evry cedex, France \\ 2: Centre de Mise en Forme (CEMEF), Mines Paristech, UMR 7635, BP 207, 06904 Sophia-Antipolis, France \\ 3: Hutchinson SA/TOTAL, Centre de Recherche, Rue Gustave Nourry, 45120 Chalette-sur-Loing, France \\ e-mail : victor.fabre@ensmp.fr, gregoire.quandalle@ensmp.fr, sabine.cantournet@ensmp.fr, \\ noelle.billon@ensmp.fr
}

Keywords: Polyamide, Matrix Composite, Water content, Glass transition, WLF

\section{Introduction}

Reinforced thermoplastics, and especially short glass fiber reinforced polyamides, due to their good stiffness and impact resistance, have been chosen as an alternative solution to metals in automotive or aeronautic applications. More precisely, those kinds of materials used near engine parts of automotives can reduce significantly weight, and so reduce $\mathrm{CO}_{2}$ gas emission. Reinforced thermoplastic automotive components are submitted to cyclic mechanical loadings in variable environmental conditions in terms of temperature and humidity. Both temperature and water content are known to degrade mechanical properties of the polyamide matrix[1]. To insure a confident mechanical design, the sensitivity of the mechanical response under these conditions have to be taken into account.

\section{Objectives}

The aim of this work is to highlight an equivalence between the strain rate, the temperature and the water content effect on the dynamic mechanical response of polyamide 6,6. The idea is to establish an expression of an equivalent strain rate at a temperature and water content of reference, based on WLF theory. Thus, it will be possible to parametrize the constitutive law with that new term, and to relay the triple sensitivity to temperature, strain rate and water content of the polyamide matrix in only one.[2]

\section{Methodology}

In the first time, PA66 samples were conditionned in climatic chambers at different relative humidity levels. Moisture uptake was checked by weighting samples during conditionning, to ensure that water equilibrium was reached. DMA analyses were performed in tension. The timetemperature superposition principle could be applied at each water content levels, and master curves have been built up. Then, tensile behaviour was explored with loading-unloading experiments for different sets of conditions in terms of temperatures,strain rates and water content. Local strains were measured using a five dots video extensometer method.

\section{Results and Analysis}

As expected [3], increasing the water content results in a steady decrease of glass transition temperature toward a limiting value. This change in glass transition temperature leads to an horizontal shift of master curves in accordance to the water content level. So, a new shift factor can be introduced, called here $b_{\omega c}$, and a new relationship has been established giving the equivalent strain-rate at a temperature and water content reference. 


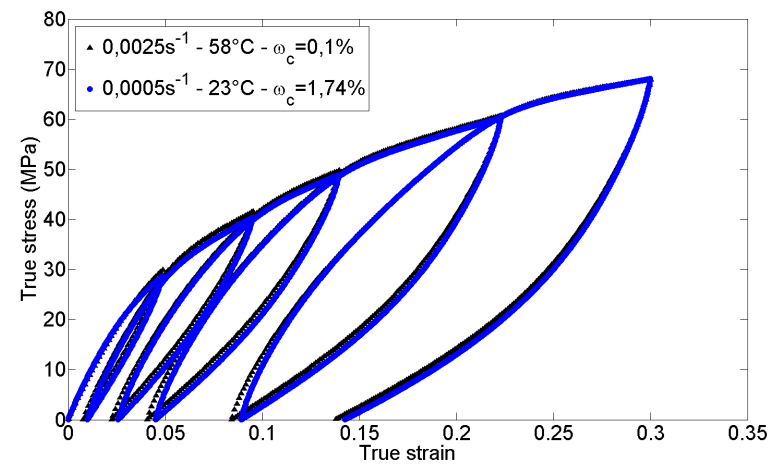

Figure 1: Time-Temperature-Water content equivalence on tensile load-unload behaviour of Polyamide 6,6 matrix

Tensile loading-unloading tests have been conducted for different set of conditions (Temperature, water content and strain rate). With two different set of conditions $\left(\left[T_{1}, \omega c_{1}\right],\left[T_{2}, \omega c_{2}\right]\right)$, it was possible to calculate the equivalent strain-rate $\dot{\varepsilon}_{2 e q}$ associated to conditions $\left(\left[T_{2}, \omega c_{2}\right]\right)$ to get the same mechanical response as the test performed at $\dot{\varepsilon}_{1}$ under conditions $\left(\left[T_{1}, \omega c_{1}\right]\right)$ (see Figure 1 ).

DMA analyses were performed on hygrothermally conditioned polyamide 6,6 specimens. At each water content level, the time-temperature superposition principle was validated. Master curves thus obtained can be superposed and the time-temperature-water content equivalence principle has been highlighted. Mechanical response equivalence was verified by load-unload tensile tests.

\section{References}

[1] D Valentin, F Paray, and B Guetta. The hygrothermal behaviour of glass fibre reinforced pa66 composites: A study of the effect of water absorption on their mechanical properties. Journal of Materials Science, 22:46-56, 1987.

[2] N. Billon. New constitutive modeling for time-dependent mechanical behavior of polymers close to glass transition: Fundamentals and experimental validation. Journal of Applied Polymer Science, 125(6):4390-4401, 2012.

[3] H. Reimschuessel. Relationships on the effect of water on glass transition temperature and young's modulus of nylon 6. Journal of polymer science, 16:1229-1236, 1978. 